\title{
Contribution to the water mite (Acari, Hydrachnidia) fauna of Turkey
}

\author{
Yunus ESEN (1) \\ Solhan Vocational School of Health Services, Bingöl University, Bingöl, Turkey \\ e-mail: yesen@bingol.edu.tr
}

Received: 6 December 2021

Accepted: 5 January 2022

Available online: 27 January 2022

ASBTRACT: This study provides new records of water mites from Erzincan, Gümüşhane and Tunceli provinces (Turkey). Thirteen species have been registered as new for the hydrachnid water mite fauna of the study area. Parathyas colligera (K. Viets, 1923) is a new record for the fauna of Turkey. So far, no water mite records have been given from the provinces of Tunceli and Gümüşhane. Including the new data, the total number of taxa recorded from Erzincan province tallies 81 species in 17 families.

Keywords: Parathyas, moist moss, new record, Turkey.

Zoobank: http://zoobank.org/E71298D2-82DA-46C1-AC9E-DC876D174D0B

\section{INTRODUCTION}

Turkey is very rich in terms of freshwater mite diversity and to date, 336 species in 62 genera and 25 families of water mites have been reported from Turkey (Erman et al., 2010, 2019; Esen, 2021). Although there have been many studies on this group in the last two decades, new records and new species are given from Turkey and the water mite fauna is still far from complete. Therefore, faunistic studies on water mites should continue for a while.

The family Hydryphantidae is third species-rich family with 39 species (in 12 genera) after families Arrenuridae (58 species) and Hygrobatidae (56 species). Up to now, only one species has been described belonging to genus Parathyas. P. palustris (K.Viets, 1923) recorded previously from Erzurum Province (Özkan and Erman, 1999).

The aim of this paper is to contribute to the knowledge of the diversity of Turkish hydrachnid water mites by studying the newly collected materials from Erzincan, Gümüşhane and Tunceli.

\section{MATERIALS AND METHODS}

Mites were collected from moss samples using BerleseTullgren funnels. Sampling studies were carried out after obtaining legal permissions from the General Directorate of Agricultural Research and Policies (50411936-604.02E.2200901) and from the General Directorate of Nature Conservation and National Parks (72784983-488.0444455 and 21264211-288.04-E.2187926), two units of TR Ministry of Agriculture and Forestry. Mite specimens were preserved in vials containing $70 \%$ ethanol. The specimens mounted in Hoyer's medium and dissected as described elsewhere (e.g., Gerecke et al., 2007). The specimens are deposited in the research collection of the Department of Biology, Bingöl University, Bingöl, Turkey.
The composition of the material is given as: (males/females/deutonymphs). All measurements are given in micrometers.

The following abbreviations are used: a.s.l. = above sea level, IV-L-6 = Fourth leg, sixth segment, Ac-3 = third acetabulum, $\mathrm{dL}=$ dorsal length $\mathrm{L}=$ length, $\mathrm{P}-1=$ palp, first segment, $\mathrm{vL}=$ ventral length, $\mathrm{W}=$ width.

\section{RESULTS}

Family: Hydrovolziidae Thor, 1905

Genus: Hydrovolzia Thor, 1905

Hydrovolzia cancellata Walter, 1906

Material examined: Moist moss on the river bank, Pülümür Valley, Tunceli, 39²15'40"N, 3952' 25"E, 1443 m a.s.l., 13.10.2018 (2/1/0).

Records from Turkey: Afyon, Muş and Rize (Erman et al., 2010).

Distribution: Central and Eastern Mediterranean, Iran (Gerecke et al., 2007; Pešić and Saboori, 2007).

Family: Hydryphantidae Piersig, 1896

Genus: Panisus Koenike, 1896

Panisus michaeli Koenike, 1896

Material examined: Wet mosses, Harşit Valley, Gümüşhane, $40^{\circ} 36^{\prime} 26^{\prime \prime} \mathrm{N}, 39^{\circ} 32^{\prime} 14^{\prime \prime E}, 2280 \mathrm{~m}$ a.s.l., 21.06.2014 $(0 / 1 / 0)$.

Records from Turkey: Konya (Boyacı and Özkan, 1994), Antalya (Boyacl et al., 2012), Burdur (Gülle et al., 2017) and Isparta (Durucan and Boyacl, 2020).

Distribution: Europe, Turkey, Iran (Pešić and Saboori, 2007; Di Sabatino et al., 2010a; Erman et al., 2010). 
Panisus torrenticolus Piersig, 1898

Material examined: Moist moss, Harşit Valley, $40^{\circ} 56^{\prime} 35 " \mathrm{~N}, 38^{\circ} 51^{\prime} 13 " \mathrm{E}, 100 \mathrm{~m}$ a.s.l., 21.03.2014 (1/0/0); Moist and grasy soil on the river bank, Sansa, Erzincan, $39^{\circ} 33^{\prime} 30^{\prime \prime} \mathrm{N}, 4^{\circ} 07^{\prime} 11^{\prime \prime E}, 1418 \mathrm{~m}$ a.s.l., 21.10.2020 $(0 / 3 / 0)$; moist moss and grasy soil on the river bank, $39^{\circ} 34^{\prime} 16^{\prime \prime N}, \quad 40^{\circ} 06^{\prime} 03^{\prime \prime E}, 1664 \mathrm{~m}$ a.s.l., 28.11.2020 $(1 / 1 / 0)$.

Records from Turkey: Afyon, Erzurum (Erman et al., 2010), Antalya (Boyacl et al., 2012) and Isparta (Durucan and Boyacı, 2020).

Distribution: Europe (except Fennoscandia), Turkey, Iran (Pešić and Saboori, 2007; Di Sabatino et al., 2010a; Erman et al., 2010).

Genus: Panisopsis K. Viets, 1926

Panisopsis thori (Walter, 1907)

Material examined: Moist and grassy soil, Ahmetli, Erzincan, 3952'49"N, 39²3'46"E, 2210 m a.s.l., 09.09.2014 $(1 / 0 / 0)$.

Records from Turkey: Erzurum, Van (Erman et al., 2010) and Burdur (Gülle et al., 2017).

Distribution: Mediterranean, Alps, Central Europe, Turkey (Di Sabatino et al., 2010a; Erman et al., 2010).

Panisopsis setipes (K. Viets, 1911)

Material examined: Moist mosses on the river bank, Pülümür Valley, Tunceli, 39¹5'40"N, 3952'25"E, 1443 m a.s.l., 13.10.2018 (1/0/0).

Records from Turkey: Isparta (Aşçı and Boyacı, 2016; Durucan and Boyacl, 2020) and Burdur (Gülle et al., 2017).

Distribution: Western Palaearctic: Northern, Central and Southern Europe, Turkey (Di Sabatino et al., 2010; Erman et al., 2019).

\section{Genus: Tadjikothyas Sokolow, 1948}

\section{Tadjikothyas connexa schwoerbeli Özkan, 1988}

Material examined: Moist moss, Pülümür Valley, Tunceli, 39³3'28"N, 39³3'28"E, 1634 m a.s.l., 27.04.2019 (0/1/0); moist moss and grasy soil on ther river bank, Sansa, Erzincan, 39³4'16"N, 4006'03"E, 28.11.2020 $(3 / 7 / 0)$; $39^{\circ} 34^{\prime} 16^{\prime \prime} \mathrm{N}, \quad 40^{\circ} 07^{\prime} 11^{\prime \prime E}, 1334 \mathrm{~m}$ a.s.l., 17.08.2020 (1/1/0).

Records from Turkey: Kayseri, Muş (Erman et al., 2010) and Burdur (Boyacl et al. 2013).

Distribution: Turkey (Erman et al., 2010).

Genus: Thyopsis Piersig, 1899

Thyopsis cancellata (Protz, 1896)
Material examined: Wet moss on the river bank, Pülümür Valley, Tunceli, 39 $24^{\prime} 28^{\prime \prime} \mathrm{N}, 39^{\circ} 51^{\prime} 15^{\prime \prime E}, 1491 \mathrm{~m}$ a.s.l., 09.09.2014 (0/1/1); 3941'59"N, 39³7'39"E, 30.01.2019 (0/2/0); Erzincan Province, Ekșisu Marshes, 3943'15"N, 39³6'46"E, 1130 m a.s.l., 12.05.2015 (0/1/0).

Records from Turkey: Erzurum (Boyacı and Özkan, 2007).

Distribution: Western Palaearctic (Di Sabatino et al., 2010a; Erman et al., 2010).

Genus: Trichothyas K. Viets, 1926

Trichothyas (Lundbladia) petrophila (Michael, 1895)

Material examined: Moist moss, Harşit Valley, $40^{\circ} 56^{\prime} 35^{\prime \prime N}, 38^{\circ} 51 ' 13 " \mathrm{E}, 100 \mathrm{~m}$ a.s.l., 21.03.2014 (1/0/0); wet moss, $40^{\circ} 36^{\prime} \mathrm{N}, 38^{\circ} 30^{\prime} \mathrm{E}, 2423 \mathrm{~m}$ a.s.l., 21.06.2014 (0/1/0); moist mosses on the river bank, Pülümür Valley, Tunceli, $39^{\circ} 15^{\prime} 40^{\prime \prime} \mathrm{N}, \quad 39^{\circ} 52^{\prime} 25^{\prime \prime} \mathrm{E}, 1443 \mathrm{~m}$ a.s.l., 13.10.2018 (0/2/0).

Record from Turkey: Afyon Erzincan and Muş, (Erman et al., 2010; Esen et al., 2013).

Distribution: Southern and Western Europe, England, Balkan, Iran, Asia Minor (Pešić and Saboori, 2007; Di Sabatino et al., 2010; Erman et al., 2010).

Genus: Parathyas Lundblad, 1926

Parathyas palustris (Koenike, 1912)

Syn. Thyas palustris Koenike, 1912

Thyas rivalis Koenike, 1912

Material examined: Moist moss, Ahmetli, Erzincan, 3957'25"N, 39²1'11"E, 2088 m a.s.l., 23.04.2014 $(1 / 1 / 1)$.

Description: Male Idiosoma L/W 1005/743, integument papillate, frontale diameter 40 , dorsal plates larger, preand postfrontale fused. Gnathosoma without short rostrum (Fig. 1E), vL 158. Palp segments $\mathrm{dL}$ and setation (in parenthesis) P-1 50 (1), P-2 84 (6), P-3 51 (2), P-4 140 (34) P-5 39 (2). Chelicera total L 226. Genital field L/W $220 / 141$, genital flap L/W 173/70, posterior margins of genital flap bearing 8-9 setae, pregenital sclerite round and separate (Fig. 1F). Ac-3 located posterior Ac-2, their basal sclerites forming less elongated stalks. Excretory pore with anterior and posterior sclerites, anterior sclerite crescent shaped (Fig. 1G).

Female Idisoma L/W 1230/940, frontal eye plate large (diameter 55), pre- and postfrontale fused (Fig. 1A). Palp segments setation same as male (Fig. 1B), palp segments $\mathrm{dL}$ and setation (in parenthesis) P-1 53 (1), P-2 105 (6), P362 (2), P-4 170 (3-4), P-5 40 (2). Chelicera total L 320. Genital field L/W 298/200, genital flap L/W 272/96, posterior margins of genital flap bearing 8-9 setae, pregenital sclerite fused with anterior genital sclerite (Fig. 1C). Excretory pore with similar anterior and posterior sclerite (Fig. 1D). 


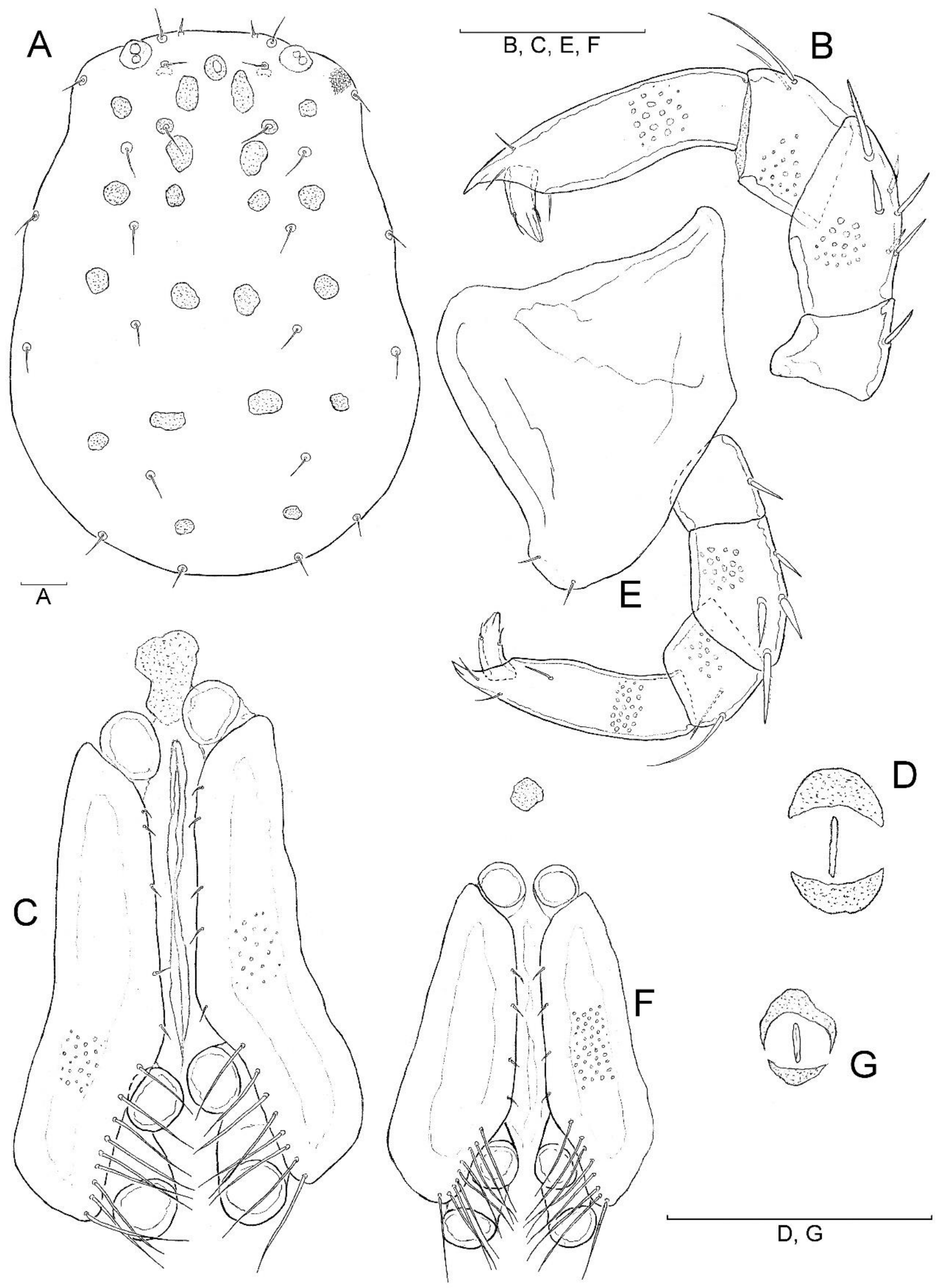

Figure 1. Parathyas palustris, female: A. Idiosoma, dorsal view, B. Palp, medial view, C. Genital field D. Excretory pore; Male: E. Gnathosoma, F. Genital field, G. Excretory pore (Scale bars $=100 \mu \mathrm{m})$. 
Records from Turkey: Erzurum (as Thyas rivalis) (Özkan and Erman, 1999).

Distribution: Holarctic (in Europe not recorded from the Iberian Peninsula); North America, Turkey (Di Sabatino et al., 2010a; Erman et al., 2010).

Parathyas colligera (K. Viets, 1923)

Syn. Thyas distinctus Tuzovskij, 2007

Material examined: Wet moss, Ahmetli, Erzincan, $39^{\circ} 52^{\prime} 54^{\prime \prime N}, \quad 39^{\circ} 20^{\prime} 31^{\prime \prime E}, 2048$ m a.s.l., 08.05 .2014 $(1 / 2 / 0)$.

Description: Male Idiosoma L/W 1106/910, integument papillate, frontale diameter 50 , dorsal plates smaller, preand postfrontale fused (Figs. 2A, 4A). Gnathosoma vL 220. Palp segments dL and setation (in parenthesis) P-1 50 (3), P-2 106 (6), P-3 60 (3), P-4 152 (3), P-5 32 (2). Chelicera total L 295. Genital field L/W 238/161, genital flap L/W $170 / 78$, posterior margins of genital flap bearing 9-10 setae, pregenital sclerite round and separate (Fig. 2B). Ac3 located posterior Ac-2, their basal sclerites forming more elongated stalks. Excretory pore with anterior and posterior sclerites, anterior sclerite crescent shaped, posterior sclerite small and roundish (Fig. 2C).

Female Idisoma L/W 1442/1160, frontal eye plate large (diameter 50), prefrontale and postfrontale not fused (Figs. 3A, 4B-C). Palp segments setation same as male (Figs 3B, C), palp segments dL and setation (in parenthesis) P-1 60 (3), P-2 112 (6), P-3 65 (2), P-4 163 (3-4), P-5 33 (2-3). Gnathosoma with short rostrum, vL 250, chelicera total L 351. Genital field L/W 297/208, genital flap L/W 240/100, posterior margins of genital flap bearing 89 setae, pregenital sclerite separate with anterior genital sclerite (Fig. 3E). Excretory pore with large anterior and small posterior sclerite (Fig. 3F).

\section{New record for Turkey}

Distribution: Germany, The Netherlands, Russia (Di Sabatino et al., 2010a).

Family: Anisitsiellidae Koenike, 1910

Genus: Bandakia Thor, 1913

\section{Bandakia concreta Thor, 1913}

Material examined: Moist moss, Ahmetli, Erzincan, $39^{\circ} 57^{\prime} 25^{\prime \prime} \mathrm{N}, \quad 39^{\circ} 21^{\prime} 11^{\prime \prime E}, 2088$ m a.s.l., 23.04.2014 $(0 / 1 / 0)$; wet moss on the river bank, Pülümür Valley, Tunceli, 39²4'28"N, 3951'15"E, 1491 m a.s.l., 09.09.2014 (0/1/0).

Records from Turkey: Isparta (Boyacı and Özkan, 2004; Durucan and Boyacı, 2020) and Antalya (Boyacı et al., 2012).

Distribution: Europe, Turkey (Di Sabatino et al., 2010a; Erman et al., 2010).
Genus: Nilotonia Thor, 1905

Nilotonia (Dartia) vietsi Bader \& Sepasgozarian, 1980

Material examined: Moist and grassy soil, Ahmetli, Erzincan, $39^{\circ} 52^{\prime} 49^{\prime \prime} \mathrm{N}, 39^{\circ} 23^{\prime} 46^{\prime \prime} \mathrm{E}, 2210 \mathrm{~m}$ a.s.l., 09.09.2014 $(0 / 1 / 0)$; wet moss, Harşit Valley, Gümüşhane, $40^{\circ} 36^{\prime} \mathrm{N}$, $38^{\circ} 30^{\prime} \mathrm{E}, 2423$ m a.s.l., 21.06.2014 (0/3/0).

Records from Turkey: Erzurum, Muş (Erman et al. 2010) and Isparta (Durucan and Boyacl, 2020).

Distribution: Iran, Turkey (Pešić and Saboori, 2007; Erman et al., 2010).

\section{Nilotonia (Dartonia) rizeensis Oezkan \& Bader, 1988}

Material examined: Wet mosses, Harşit Valley, Gümüşhane, $40^{\circ} 43^{\prime} 28^{\prime \prime} \mathrm{N}, \quad 39^{\circ} 02^{\prime} 40^{\prime} \mathrm{E}, \quad 730 \mathrm{~m}$ a.s.l., 23.11.2013 (0/1/1).

Records from Turkey: Rize (Oezkan and Bader, 1988).

Distribution: Turkey (Erman et al., 2010; Esen et al., 2017).

Remark: This is the second record from Turkey except the type locality. To date, only the female of Nilotonia (Dartonia) rizeensis is known from Rize Province. In the collected specimens from Gümüșhane Province, a female and a deutonymph were found. The dorsal plates of deutonymph are similar with adults. There are two pairs of genital acetabulae in the genital field. Bearing a ventrodistally projection on pedipalp femur and three setae on the tip of the last segment of fourth leg are the most important characteristic features of adults. Although the general palp shape of deutonumph is similar to adults, there is no projection on P-2. Further, unlike adult individuals, there are two setae on the tip of the last segment of the fourth leg. Figure $5 A-G$ show some morphological details of female and deutonymph from Gümüşhane Province.

\section{DISCUSSION}

In this study totaly thirteen species belonging to families Hydrovolzidae, Hydryphantidae and Anisitsiellidae recorded from Erzincan, Gümüşhane and Tunceli provinces. All species are new for study area. Parathyas colligera (K. Viets, 1923) is newly recorded from Turkey. P. palustris (as Thyas rivalis) is previously recorded from Erzurum province by Özkan and Erman (1999). They stated that $T$. rivalis and $T$. palustris are very similar species, and whether they are synonymous or not can only be decided by examining more specimens of both species.

Thyas Koch, 1836, Todothyas Cook, 1974 and Acerbitas Özdikmen, 2006 are synonymized with Parathyas Lundblad, 1926 by Di Sabatino et al. (2010b). Previously, Tuzovskij (2007) proposed to synonymize Parathyas Lundblad, 1926 with Thyas, Koch. There are not significant differences between the type species of Parathyas and the character states diagnostic for Thyas. Thus, Di Sabatino et al. (2010b) refused the former subdivision of 

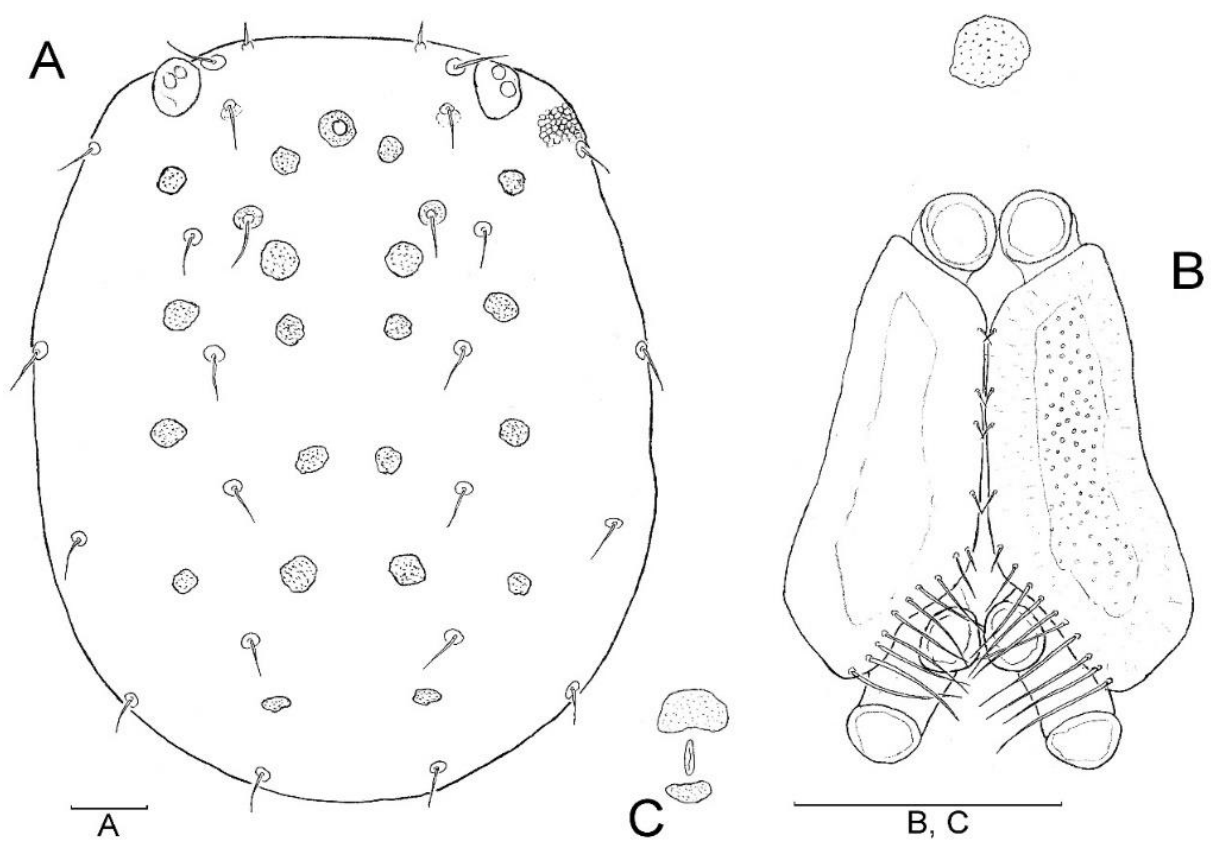

Figure 2. Parathyas colligera, male: A. Idiosoma, dorsal view, B. Genital field, C. Excretory pore (Scale bars = $100 \mu \mathrm{m}$ ).

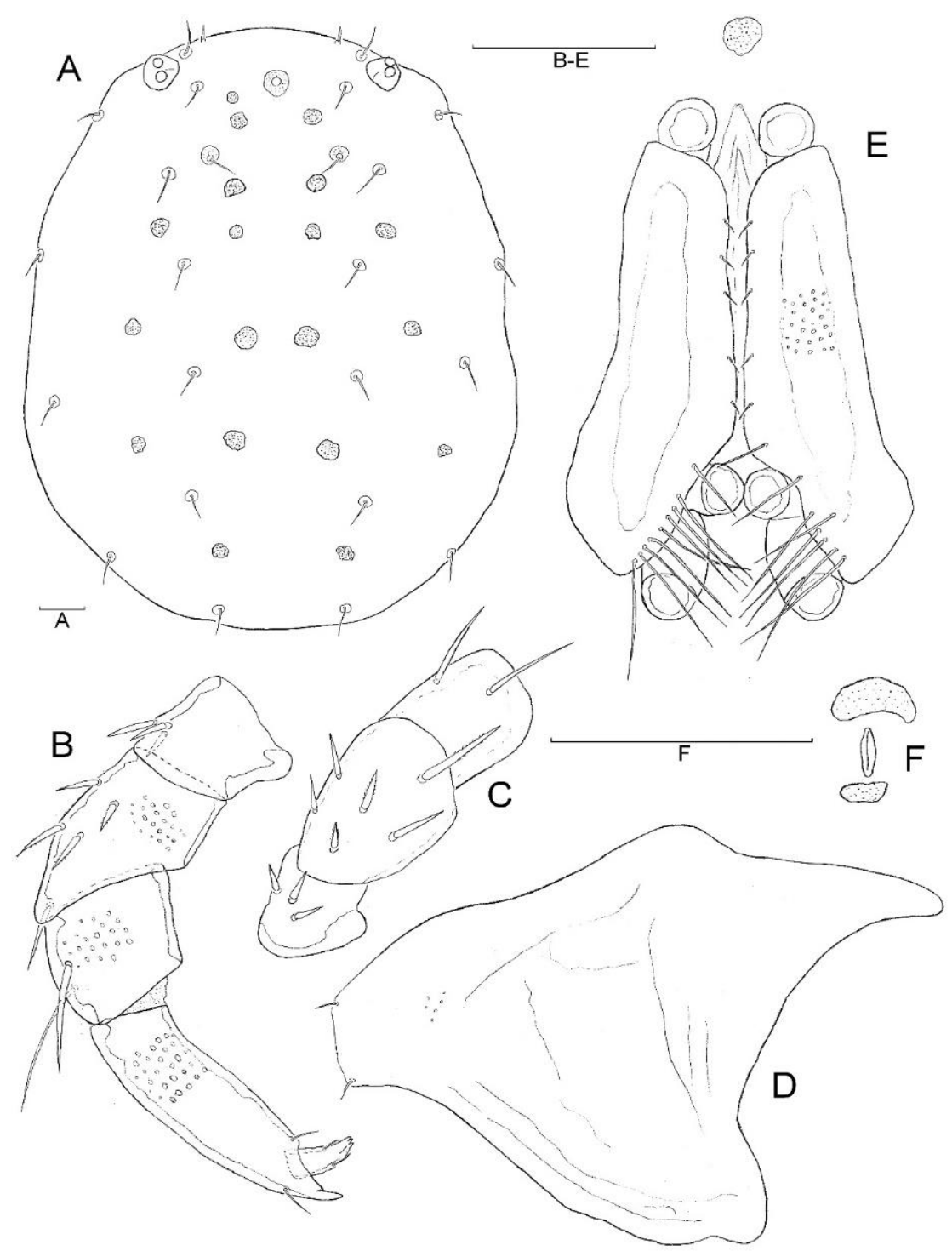

Figure 3. Parathyas colligera, female: A. Idiosoma dorsal view, B. Palp, lateral view, C. Palp, dordal view, D. Capitulum, lateral view, E. Genital field, F. Excretory pore (Scale bars $=100 \mu \mathrm{m}$ ). 

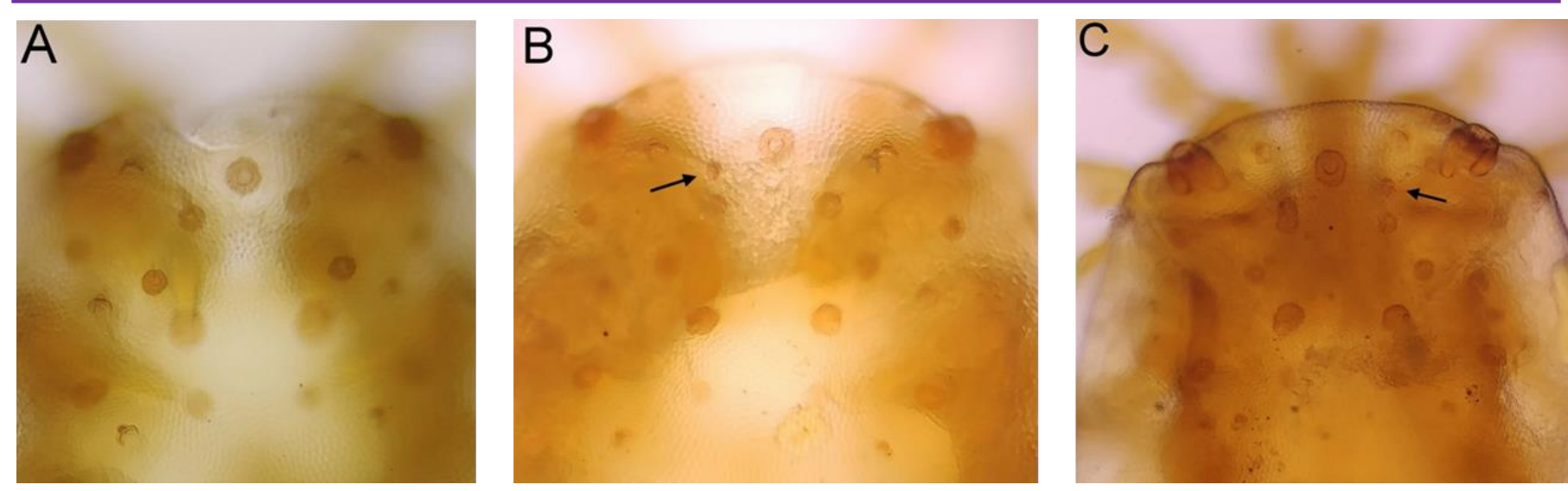

Figure 4. Parathyas colligera, A. Frontal area of male, B-C. Frontal area of female (arrows indicate prefrontale variability in females).
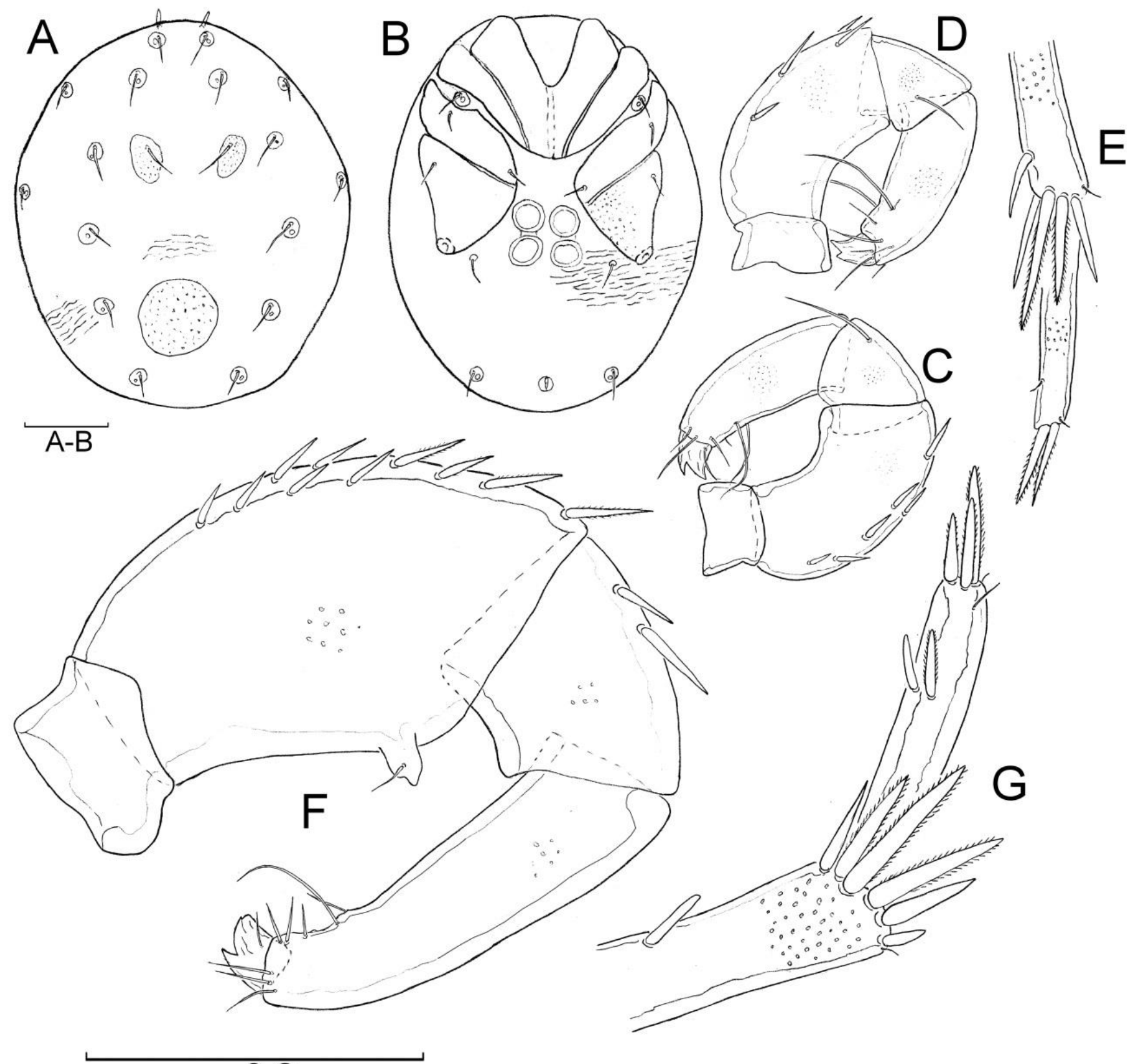

C-G

Figure 5. Nilotonia (Dartonia) rizeensis, deutonymph: A. Idiosoma, dorsal view, B. Idiosoma, ventral view, C. Palp medial view, D. Palp, lateral view, E. IV-L-6; Female: F. Palp, medial view, G. IV-L-6 (Scale bars = $100 \mu \mathrm{m})$. 
the genus into subgenera and all species formerly placed in Thyas tranferred to Parathyas.

Parathyas colligera (K.Viets, 1923) is very similar to $P$. palustris Koenike, 1912 by the gnathosoma with longer rostrum and diameter of frontal eye platelet approximately equal to length of lateral eye capsule. $P$. colligera can be easily distinguished from $P$. palustris due to the P-1 with three setae, dorsal plates smaller, Ac-3 basal sclerites forming more elongated stalks, pre- and postfrontale separated. The specimens of $P$. colligera collected from Erzincan province differs in having shorter rostrum, P-3 with two setae (in European specimens P-3 with four setae - see Di Sabatino et al. (2010a)) and male pre- and postfrontale fused (Fig. 4A). In females, prefrontale is shown variability in absence to right or left side (Figs 4B, C). In addition, the pregenital sclerite fused with the anterior genital sclerite in females of $P$. palustris (Fig. 1C).

\section{Statement of ethics approval}

Not applicable.

\section{Funding}

This study was prepared mainly based on the mite materials collected from the project FBA-2019-642 supported by the Scientific Research Fund of Erzincan Binali Yıldırım University (EBYU) and a project $118 Z 469$ supported by the Scientific and Technological Research Council of Turkey (TÜBİTAK).

\section{Conflict of interest}

No potential conflict of interest was reported by the author.

\section{Acknowledgements}

I am indebted to Dr. Salih Doğan (Erzincan Binali Yıldırım University, Turkey) for sending me mite specimens, and two anonymous referees for their careful work and valuable comments.

\section{REFERENCES}

Aşçı, F. and Boyacı, Y.Ö. 2016. Türkiye su kenesi faunası için yeni bir su kenesi türü Panisopsis setipes (Viets, 1911) (Acari, Hydrachnidia). Kafkas Üniversitesi Fen Bilimleri Enstitüsü Dergisi, 9 (2): 1-2. [In Turkish]

Boyacı, Y.Ö. and Özkan, M. 1994. Konya ilinden Türkiye faunası için yeni su kenesi (Acari, Hydrachnellae) türleri-I. XII. Ulusal Biyoloji Kongresi, 6-8 July, 1994, Edirne, Turkey, 191-201. [In Turkish]

Boyacı, Y.Ö. and Özkan, M. 2004. Two new records of water mites (Hydrachnidia, Acari) for the Turkish fauna: Bandakia concreta Thor, 1903 and Brachypoda mutila Walter, 1928. Turkish Journal of Zoology, 28: 279-284.

Boyacı, Y.Ö. and Özkan, M. 2007. A systematic and ecologic research of water mites (Acari, Hydrachnidia) in Akdağ and Dumlu Streams. Ege Üniversitesi Su Ürünleri Dergisi, 24 (1-2): 113-115. [In Turkish]
Boyacı, Y.Ö., Gülle, P. and Gülle, İ. 2012. Water mite (Hydrachnidia) fauna of Köprüçay River (Antalya) and its branches. Süleyman Demirel Üniversitesi Fen Bilimleri Enstitüsü Dergisi, 16 (1): 29-32. [In Turkish]

Boyacı, Y.Ö., Gülle, P., Didinen, H. and Yıldırım, M.Z. 2013. Water mite (Hydracnnidia: Acari) fauna of Lakes Region (Turkey). International Journal of Ecosystems and Ecology Sciences, 3 (4): 675-678.

Di Sabatino, A., Gerecke, R., Gledhill, T. and Smit, H. 2010a. Chelicerata: Acari II. In: Süßwasserfauna von Mitteleuropa., Gerecke, R. (Ed.). Vol. 7: 2-2, Elsevier GmbN, Spektrum Akademischer Verlag, München, Germany, 1-134. doi: 10.1007/978-3-8274-2266-8

Di Sabatino, A., Gerecke, R., Gledhill, T. and Smit, H. 2010b. The taxonomic status of the water mite genera Todothyas Cook and Parathyas Lundblad-supplement to Di Sabatino et al. (2009). Zootaxa, 2361: 2368. doi: 10.11646/zootaxa.2361.1.6

Durucan, F. and Boyacı, Y.Ö. 2020. The water mites (Acari: Hydrachnidia) of Isparta province, Turkey. Acta Aquatica Turcica, 16 (3): 366-369. doi:10.22392/actaquatr.692323

Erman, O., Pešić, V., Esen, Y. and Özkan, M. 2010. A checklist of the water mites of Turkey (Acari: Hydrachnidia) with description of two new species. Zootaxa, 2624: 148.

doi:10.11646/zootaxa.2624.1.1

Erman, O., Gülle, P., Özkan, M., Candoğan, H. and Boyacı, Y.Ö. 2019. Checklist of the water mites (Acari: Hydrachnidia) of Turkey: First supplement. Zootaxa, 4686 (3): 376-396.

doi:10.11646/zootaxa.4686.3.4

Esen, Y. 2021. A new record of the genus Sperchon (Acari: Hydrachnidia, Sperchontidae) from Turkey. Acarological Studies, 3 (1): 48-50. doi:10.47121/acarolstud.860097

Esen, Y., Dilkaraoğlu, S. and Erman, O. 2013. A systematic study on water mites (Acari, Hydrachnidia) of Kemaliye district (Erzincan province). Turkish Journal of Entomology, 37 (3): 263-276.

Esen, Y., Doğan, S., Doğan, S. and Erman, O. 2017. First description of deutonymph of Nilotonia rizeensis Oezkan \& Bader, 1988 (Acari, Hydrachnidia). III. International Congress on Zoology and Technology, 1517 July, 2017, Afyonkarahisar, Turkey, p. 97.

Gerecke, R., Weigmann, G., Wohltmann, A. and Wurst, E. 2007. Order Acari - General introduction and key to major groups. In: Süßwasserfauna von Mitteleuropa. Gerecke R. (Ed.). Vol. 7: 2-1, Elsevier GmbH, Spektrum Akademischer Verlag, München, Germany, 14-57. doi: 10.1007/978-3-662-55958-1_2 
Gülle, P., Gülle, İ. and Boyacı, Y.Ö. 2017. Water mites (Hydrachnidia: Acari) fauna of Burdur province, Turkey. The Journal of Graduate School of Natural and Applied Sciences of Mehmet Akif Ersoy University, 8 (Supp. 1): 218-220. [In Turkish]

doi: 10.29048/makufebed.330538

Oezkan, M. and Bader, C. 1988. Description of two new species and supplementary remarks on the water-mite fauna of Turkey (Acari, Actinedida, Hydrachnellae). Archiv für Hydrobiologie, 114: 133-145.

Özkan, M. and Erman, 0. 1999. A new Thyas Koch, 1836 (Acari, Hydrachnellae) species for Turkish fauna. Turkish Journal of Zoology, 23: 811-815 [In Turkish].
Pešić, V. and Saboori, A. 2007. A checklist of the water mites (Acari: Hydrachnidia) of Iran. Zootaxa, 1473: 4568.

doi: 10.11646/zootaxa.1473.1.3

Tuzovskij, P.V. 2007. Water mites of the genus Thyas Koch, 1835 (Acariformes: Thyadidae) in Russia. Acarina, 15 (2): 173-259.

Edited by: Orhan Erman

Reviewed by: Two anonymous referees

Citation: Esen, Y. 2022. Contribution to the water mite (Acari, Hydrachnidia) fauna of Turkey. Acarological Studies, 4 (1): 28-35. 